\title{
Strategi Marketing Public Relations Grab Melalui Pembayaran OVO
}

\author{
Dhea Salsabila Royan ${ }^{2 *}$, A.S Haris Sumadiria1 ${ }^{1}$, Lida Imelda Cholidah \\ $2^{2}$ \\ 1Jurusan Ilmu Komunikasi Jurnalistik, Fakultas Dakwah dan Komunikasi, UIN Sunan \\ Gunung Djati, Bandung \\ ${ }^{2}$ Jurusan Ilmu Komunikasi Hubungan Masyarakat, Fakultas Dakwah dan Komunikasi, \\ UIN Sunan Gunung Djati, Bandung \\ *Email :dheasalsaroyan@gmail.com
}

\begin{abstract}
ABSTRAK
Penelitian ini bertujuan untuk mengetahui bagaimana Strategi Marketing Public Relations dalam menarik perhatian costumer dalam pembayarannya menggunakan OVO, mengetahui bagaimana Strategi Marketing Public Relations dalam mendorong minat costumer dalam pembayarannya menggunakan OVO, serta untuk mengetahui bagaimana Strategi Marketing Public Relations dalam menggiring opini publik yang beredar di masyarakat. Penelitian ini menggunakan konsep Three Ways Strategy yang digagas oleh Phillip Kotler yaitu Push, Pull and Pass Strategy dengan hasil penelitian menunjukkan bahwa kegiatan yang dilakukan Marketing Public Relations Grab dalam menarik perhatian pengguna Grab yaitu dengan mengadakan event, memberikan potongan harga, kupon dan koin menarik yang bisa didapatkan setelah menggunakan Grab, dalam mendorong minat pennguna Grab yaitu dengan memasang iklan di media sosial, menggandeng public figure, dan memasang google adsense youtube. Kegiatan yang dilakukan Marketing Public Relations Grab untuk menggiring opini publik yaitu dengan memberikan informasi yang benar terkait jasa yang Grab tawarkan di berbagai media sosial.
\end{abstract}

Kata Kunci : Strategi Marketing Public Relations; Push, Pull and Pass Strategy.

\section{ABSTRACT}

This study aims to find out how Public Relations Marketing Strategies in attracting the attention of customers in payments using OVO, knowing how Public Relations Marketing Strategies in encouraging customer interest in payments using OVO, and to find out how Public Relations Marketing Strategies in lead public opinion that develops in society. The method used in this research is a qualitative case study with data collection 
techniques through in-depth interviews with Grab staff working in the field of Business Development and Driver Grab as informants. Data collection is also collected through passive participatory observation. This study uses the concept of Three Ways Strategy which was initiated by Phillip Kotler namely Push, Pull and Pass Strategy with the results of the study showing that the activities carried out by Grab for Pull Strategy are by bolding events, providing various attractive promos and discounts that generate rewards and points After using OVO, the Push Strategy conducted by Grab is to promote Grab through social media such as Instagram, Twitter and Youtube. Grab's Pass Strategy is to lead public opinion by providing true information related to the services Grab offers on various social media as a means of disseminating information.

Keywords: Strategy of Marketing Public Relations; Push, Pull and Pass Strategy.

\section{PENDAHULUAN}

Marketing Public Relations merupakan gabungan dari Marketing dan Public Relations. Pengertian secara umum Marketing Public Relations yaitu praktisi humas yang berada di bidang pemasaran dengan melakukan peranan untuk membuat pelanggan atau pengguna suatu barang atau jasa tetap berada di pihak perusahaan, serta berusaha untuk mempertahankan kepercayaannya terhadap perusahaan itu.

Irianti (2018) dalam Jurnal yang berjudul "Marketing Public Relations dalam Meningkatkan Loyalitas Pelanggan" Vol.03 No.03 menyebutkan bahwa Marketing Public Relations sebagai alat komunikasi pemasaran yang memadukan pelaksanaan program dan strategi pemasaran (Marketing Strategi Implementation) dengan aktivitas program kerja PR (Work Program of Public Relations), Marketing public relations dalam konsepnya terdapat tiga taktik atau yang sering dikenal Three Ways Strategy untuk melaksanakan suatu program dalam mencapai tujuan, yaitu : Pertama public relations merupakan potensi untuk menyandang suatu taktik pull strategy (menarik), sedangkan kedua merupakan power sebagai penyandang push strategy (untuk mendorong) dalam hal pemasaran, dan taktik ketiga pass startegy sebagai upaya untuk mempengaruhi atau menciptakan opini publik yang menguntungkan.

Grab merupakan sebuah platform yang menyediakan berbagai macam layanan kebutuhan sehari hari untuk penggunanya mulai dari jasa perjalanan, jasa antar makanan sampai dengan bisa melakukan pembayaran mengunakan aplikasi atau disebut juga dompet digital.

Kemunculan aplikasi Grab ini sangat mempermudah orang untuk melakukan aktivitas yang mereka kerjakan dengan cepat dan tidak memakan banyak waktu. Selain mempermudah pekerjaan, keberadaan Grab menjadi 
salah satu hal yang sepertinya wajib dimiliki semua pengguna telepon pintar karena bukan hanya unggul dalam pelayanan jasa saja, aplikasi ini juga dapat menjadikannya sebagai dompet digital yang bisa digunakan kapan saja.

Salah satu yang menjadi daya tarik aplikasi Grab yaitu kemudahan metode pembayarannya yang menggunakan OVO. OVO adalah salah satu layanan yang berhubungan dengan keuangan digital berasal dari Indonesia yang fungsinya sebagai alat untuk mempermudah pengguna untuk bertransaksi. OVO juga merupakan salah satu perusahaan unicorn yang digunakan oleh banyak orang dengan berbagai keuntungan yang dimilikinya.

Keuntungan yang ditawarkan OVO di aplikasi Grab menjadi daya tarik tersendiri karena dengan adanya OVO, proses pembayaran ketika kita menggunakan jasa dari fitur Grab akan lebih cepat, fleksibel dan mudah. Berbagai jenis promosi yang dicantumkan di laman Grab yang berhubungan dengan OVO membuat konsumen lebih tertarik lain untuk menggunakan jasa Grab.

Penelitian pertama yaitu penelitian yang telah dilakukan oleh Dwi Asri Rachmawati yang merupakan salah satu mahasiswa jurusan ilmu komunikasi humas di UIN Sunan Gunung Djati Bandung tahun 2018 yang berjudul "Strategi Marketing Public Relations Daarut Tauhid Dalam Mempertahankan Loyalitas Jama'ah" (Studi Deskriptif Pada Humas Daarut Tauhid). Penulis tersebut menjelaskan strategi MPR yang ada di Daarut Tauhid. Penelitian ini berisi tentang bagaimana cara pengelolaan dan cara praktisi MPR dalam strateginya menjaga loyalitas pelanggan. Hasil penelitiannya yaitu strategi yang dilakukakn oleh praktisi MPR berjalan cukup baik sesuai dengan tujuan dan target yang ingin dicapai. Perbedaan peneliti yang dilakukan penulis dengan penelitian ini yaitu penelitian ini difokuskan kepada loyalitas jama'ah.

Penelitian kedua yaitu penelitian yang telah dilakukan oleh Ulfah Izzatun Syahidah yang merupakan salah satu mahasiswa jurusan ilmu komunikasi humas di UIN Sunan Gunung Djati Bandung tahun 2017 yang berjudul "Strategi Maketing Public Relations PT. Eigerindo Multi Produk Industri Dalam Pembentukkan Brand Image Eiger". Penelitian ini menjelaskan tentang strategi MPR dalam pembentukkan brand dengan mengetahui strategi apa saja yang dilakukan pihak perusahaan. Perbedaan peneliti yang dilakukan penulis dengan penelitian ini yaitu penelitian ini difokuskan kepada strategi dalam pembentukkan brand image sebagai merek yang telah dikenal luas oleh publik.

Penelitian ketiga yaitu penelitian dalam bentuk jurnal yang ditulis oleh Anil Hukmah dan Harfinah yang merupakan mahasiswa dari Program Studi Ilmu Komunikasi, Fakultas Ilmu Sosial Dan Ilmu Politik Universitas Islam 
Makassar tahun 2018 yang berjudul "Analisis Faktor yang Mempengaruhi Kepuasan Penumpang Grab di Makassar". Penelitian ini berisi tentang seberapa besar pengaruh yang dihasilkan dari rating atau bintang yang diberikan pelanggan Grab kepada pengemudi atau pelaku pelayanan jasa sebagai publik dari perusahaan. Faktor kepuasan menjadi kunci utama penelitian ini dengan berfokus kepada pengguna aplikasi Grab di Makassar saja.

Penelitian keempat yaitu penelitian berupa jurnal bernama Magdalena Elvina tahun 2016 yang berjudul "Sikap Masyarakat Jakarta Pengguna Aplikasi Grab Terhadap Brand Baru Grab". Penelitian ini berisi tentang sikap pengguna Grab yang berada di kawasan Jakarta terhadap Brand baru atau Rebranding Grab dari semula GrabTaxi menjadi Grab saja. Hasilnya beberapa orang diantara informan yang ada, mereka tidak merasakan perbedaan yang signifikan dan tetap menyukai layanan Grab.

Penelitian kelima yaitu berupa jurnal dengan penulis bernama Fatimah Abdillah, seorang mahasiswa STIE Pandu Madania pada tahun 2017 dengan judul "Efektivitas Marketing Public Relations dalam Membangun Citra Merek Perusahaan Jasa Telekomunikasi". Peneliti melakukan penelitian di PT. Smartfren Telekomunikasi dengan memfokuskan penelitiannya kepada citra atau image perusahaan dalam keefektifannya dalam kegiatan Marketing Public Relations di perusahaan tersebut.

Lokasi penelitian yang dilakukan yaitu di kantor Grab cabang Paskal Hypersquare, Jl.Pasir Kaliki Blok F35-37 No.27-29 Kebon Jeruk, Kecamatan Cicendo, Kota Bandung, Jawa Barat. Berdasarkan lokasi penelitian yang akan dilaksanakan, lokasi kantor yang menjadi salah satu cabang kantor Grab di Bandung memiliki ketersediaan sumber data yang bisa dijadikan bahan penelitian untuk peneliti dan memiliki informan yang dijadikan sebagai narasumber ketika peneliti mencari informasi melalui wawancara dan observasi.

Penelitian ini bertujuan untuk mengetahui bagaimana Strategi Marketing Public Relations dalam menarik perhatian costumer dalam pembayarannya menggunakan OVO, mengetahui bagaimana Strategi Marketing Public Relations dalam mendorong minat costumer dalam pembayarannya menggunakan OVO, serta untuk mengetahui bagaimana Strategi Marketing Public Relations dalam menggiring opini publik yang beredar di masyarakat.

Metode penelitian yang digunakan penulis untuk penelitian ini adalah metode deskriptif kualitatif. Metode ini diambil karena untuk mendeskripsikan serta mengbambarkan fenomena yang peneliti lakukan. 
Peneliti tidak memanipulasi atau mengubah suatu variabel atau objek penelitian melainkan hanya menggambarkan dan mendeskripsikan kejadian sesuai dengan keadaan.

\section{LANDASAN TEORITIS}

Marketing Public Relations adalah suatu proses dari perencanaan, pelaksanaan dan evaluasi program-program yang mendorong atau menganjurkan pembelian dan kepuasan konsumen melalui komunikasi yang credible dalam menyampaikan informasi dan menciptakan impresi yang mengidentifikasi perusahaan dan produknya dengan kebutuhan, keinginan, perhatian dan kepentingan konsumen. Ruslan (2006:35) mendefinisikan Marketing Public Relations sebagai perpaduan sinergi antara pelaksanaan program dan strategi pemasaran dengan aktivitas program kerja humas dalam upaya meluaskan pemasaran demi mencapai kepuasan konsumennya.

Marketing Public Relations dianggap menjadi strategi yang lebih hemat untuk mencapai target publisitas tinggi dalam publikasi serta juga dapat membantu dalam pembentukan citra perusahaan itu sendiri. Peranan Marketing Public Relations ini dimaksudkan agar dapat mengembangkan produk (jasa taleny modeling) ataupun perusahaan sesuai dengan target yang ingin dicapai.

Menurut Stepehen P. Robbins dalam buku Scott M. Cutlip, Allen dan Glenn. M Broom (2006: 353) mendefinisikan strategi adalah sebagai bentuk penentuan tujuan dan sasaran usaha jangka panjang dan adopsi pelaksanaan dan alokasi sumber saya yang diperlukan untuk mencapai tujuan tersebut. Strategi Marketing Public Relations adalah sebuah perencanaan manajemen perusahaan yang disusun sedemikian rupa yang bertujuan untuk memajukan atau mengembangkan sebuah perusahaan yang dibuat secara terencana untuk jangka panjang dan jangka pendek, sehingga Posture Management mengetahui langkah apa yang akan ditempuh dalam menghadapai sebuah permasalahan khususnya masalah yang sedang dihadapi sekarang adalah keberadaan pesaing yang semakin pesat.

Marketing Public Relations mempunyai titik penekan bukan pada selling namun pada pemberian informasi, pendidikan dan upaya peningkatan pengertian lewat penambahan pengetahuan mengenai suatu merek produk barang atau jasa dari suatu perusahaan agar lebih kuat dampaknya dan lebih lama diingat oleh oleh konsumen dengan tingkat komunikasi yang lebih intensif dan komprehensif bila dibandingkan dengan iklan, maka Marketing Public Relations merupakan suatu konsep yang lebih tinggi dari iklan yang biasa. 
Marketing Public Relations suatu proses perencanaan, pelaksanaan dan pengevaluasian program-program yang memungkinkan terjadinya pembelian dan kepuasan konsumen melalui komunikasi yang baik mengenai informasi dari perusahaan terhadap citra merek (Brand Image) suatu produk maka dari itu dalam konsep Marketing Public Relations saat ini setidaknya ada tiga disiplin ilmu yang tergabung didalamnya; strategi, pemasaran dan kehumasan.

Strategi Marketing Public Relations adalah sebuah perencanaan manajemen perusahaan yang disusun sedemikian rupa yang bertujuan untuk memajukan atau mengembangkan sebuah perusahaan yang dibuat secara terencana untuk jangka panjang dan jangka pendek, sehingga Posture Management mengetahui langkah apa yang akan ditempuh dalam menghadapai sebuah permasalahan khususnya masalah yang sedang dihadapi sekarang adalah keberadaan pesaing yang semakin pesat.

Strategi adalah rencana yang disatukan, luas berintegrasi yang menghubungkan keunggulan strategis perusahaan dengan tantangan lingkungan, yang dirancang untuk memastikan bahwa tujuan utama dari perusahaan dapat dicapai melalui pelaksanaan yang tepat oleh organisasi. Kata strategi berasal dari bahasa Yunani "Strategia" yang diartikan sebagai "the art of the general" atau seni seorang panglima yang biasanya digunakan dalam peperangan.

Menurut Effendy (2004: 97), Strategi adalah perencanaan (Planning) dan manajemen untuk mencapai suatu tujuan. Dalam pencapain tujuan tidak hanya dibutuhkan sebuah peta jalan satu arah saja, melainkan harus mampu menunjukan taktik operasionalnya.

Menurut Stepehen P. Robbins dalam buku Scott M. Cutlip, Allen dan Glenn. M Broom (2006: 353) mendefinisikan strategi adalah sebagai bentuk penentuan tujuan dan sasaran usaha jangka panjang dan adopsi pelaksanaan dan alokasi sumber saya yang diperlukan untuk mencapai tujuan tersebut.

Ruslan (2007 :133), Ahmad Adna Putra mengatakan bahwa strategi adalah bagian terpadu dari suatu rencana (plan) sedangkan rencana merupakan produk dari perencanaan yang akhirnya perencanaan adalah salah satu fungsi dari manajemen.

Dalam pemasaran, apabila buman relations terjalin dengan baik, maka pemasaran dapat mencapai target yang diinginkan sesuai dengan sasaran awal pemasaran. Menurut Effendy ada empat macam teknik komunikasi yang biasa digunakan, antara lain: informatif, persuasif, koersif dan hubungan manusiawi. Menurutnya hubungan manusiawi adalah interaksi antara seseorang dengan orang lain dalam segala situasi dan dalam semua 
bidang kehidupan. Jadi hubungan manusiawi dilakukan dimana saja: di rumah, di jalan, dalam bis, dalam kereta api dan sebagainya. Keberhasilan seseorang dalam melakukan hubungan manusiawi ialah karena ia bersifat manusiawi: ramah, sopan, hormat, menaruh penghargaan, dan lain-lain sikap yang bernilai luhur.

Human relations merupakan keseluruhan rangkaian hubungan di dalam suatu organisasi baik secara formal dalam suasana kedinasan maupun hubungan informal dalam bentuk kunjungan kekeluargaan akan mempengaruhi terhadap meningkatnya gairah kerja dan terhadap kesungguhan orang-orang yang dalam organisasi atau perusahaan, sehingga dapat memberikan pelayanan yang baik kepada pegawai lainnya.

Untuk mencapai kesuksesan pemasaran, iklan menjadi sarana yang tepat dalam upaya untuk pencapaian target. Iklan memiliki peranan yang penting dalam sebuah proses komunikasi pemasaran karena iklan sebuah sarana yang paling populer dikalangan konsumen dalam mempromosikan suatu produk atau jasa. Sebuah perusahaan, iklanlah yang biasanya menghabiskan dana paling banyak. oleh karena itu perusahaan harus lebih bijaksana berhati-hati dalam memilih dan melakukan proses periklanan agar tidak terjadi suatu tindakan yang dapat menghasilkan suatu kesia-sian dalam melakukan kegiatan periklanan.

Media periklanan yang sering digunakan dan dianggap sangat penting yaitu media sosial. Pada era digital saat ini, media sosial menjadi media yang wajib bagi sebuah instansi atau perusahaan memasang iklan dalam media sosial. Ada beberapa macam media sosial yang sering dipakai dalam memasang iklan. Media sosial yang dipilih merupakan media sosial yang paling banyak digunakan oleh masyarakat luas sebagai sasaran periklanan.

Media sosial yang paling banyak digunakan biasanya akan lebih banyak mengandung iklan yang bersponsor. Iklan yang ditampilkan di media sosial juga akan disesuaikan dengan pengguna media tersebut dengan memilih konten apa yang sesuai dengan iklan. Media sosial seolah dianggap sebagai media utama dalam periklanan mengingat pada saat ini media sosial lah yang lebih sering digunakan daripada media cetak atau media elektronik. Kebutuhan manusia dengan smartphone menjadi kunci utama mengapa iklan di media sosial sangatlah penting dan dinilai yang paling bisa mempengaruhi keberhasilan periklanan.

Konsep Marketing Public Relations secara garis besarnya terdapat tiga taktik (Three Ways Strategy) sebagai perwujudan kegiatan Marketing Public Relations dari strategi Public Relations menurut Rosady Ruslan (2010:2) agar dapat melaksanakan program dalam mencapai tujuan (goals), yaitu: Pull 
Strategy (Menarik) yaitu seorang Public Relations memiliki potensi dalam menerapkan suatu taktik untuk menarik perhatian publik dengan berbagai cara guna mengupayakan tercapainya tujuan perusahaan serta peningkatan penjuaan baik barang ataupun jasa. Push Strategy (Mendorong) yaitu Upaya dengan menerapkan taktik mendorong atau merangsang meningkatkan jumlah pembelian sehingga dapat meningkatkan angka penjualan. Pass Strategy (Mempengaruhi) yaitu sebagai upaya mempegaruhi atau menciptakan opini publik menguntungkan melalui berbagai kegiatan, partisipasi dalam kegiatan kemasyarakatan tanggung jawab sosial serta kepedulian masalah yang berkaitan dengan kondisi dan lingkungannya.

Dari taktik yang sudah dipaparkan, penulis mengambil kesimpulan bahwa ketiga taktik ini memiliki kemampuan cukup efektif dalam kegiatan pemasaran yaitu promosi. Masing-masing tahapan taktik tersebut dapat membantu merangsang keberadaan talent modeling serta posture management $\mathrm{di}$ mata pelanggan.

\section{HASIL DAN PEMBAHASAN}

Pada hasil penelitian ini, guna mendapatkan hasil penelitian yang tepat untuk mencapai tujuan penelitian yang diinginkan peneliti, peneliti melakukan wawancara mendalam (indept interview) kepada informan yang sebelumnya peneliti telah melakukan observasi ke kantor Grab cabang Bandung yang berada di Paskal Hypersquare, Jl. Pasir Kaliki Blok F35-37 No.27-29 Kebon Jeruk, Kecamatan Cicendo, Kota Bandung, Jawa Barat.

Observasi ini dilanjutkan dengan wawancara kepada informan yang dilakukan secara online. Waktu observasi hingga wawancara dilakukan di bulan Februari sampai bulan Juni 2020. Wawancara ini dilakukan untuk mendapatkan data dan informasi sesuai dengan metode penelitian yang peneliti gunakan dengan penyajian data disajikan melalui data deskriptif. Berdasarkan penelitian yang telah dilakukan peneliti, strategi Marketing Public Relations yang diterapkan didalam perusahaan Grab ini yaitu menggunakan Three Ways Strategy yang memiliki 3 tahap yaitu tahap Pull Strategy, Push Strategy dan Pass Strategy yang telah dirangkum sebagai berikut.

\section{Strategi Marketing Public Relations dalam Menarik Perhatian Pengguna Grab Melalui Pembayaran OVO}

Strategi Marketing Public Relations yang digunakan Grab Bandung sebagai upayanya untuk mencapai tujuan perusahaannya yang pertama yaitu Pull Strategy. Strategi yang Grab lakukan dalam menarik perhatian khalayak atau publik ini bertujuan untuk meningkatkan awareness dari publik dengan usaha awalnya yaitu memperkenalkan Grab kepada masyarakat Indonesia yang 
pada awalnya belum terbiasa dengan layanan jasa perjalanan online, tapi dengan banyaknya iklan yang diberikan Grab kepada khalayak, Grab menjadi platform digital yang sangat terkenal sampai sekarang dan bisa masuk kedalam kebutuhan yang penting untuk masyarakat Indonesia.

Hasil penelitian menjelaskan bahwa dalam tahap ini, strategi yang digunakan oleh perusahaan berupa tahap awal dalam pemasaran. Perusahaan pada awalnya ingin memperkenalkan lebih jauh mengenai Grab ini. Grab memiliki upaya-upaya untuk memperkenalkan perusahaannya berupa sebuah aplikasi yang menawarkan berbagai antar jasa perjalanan online yang terus berkembang sampai saat ini. Beliau juga menjelaskan lebih dalam lagi taktik apa saja untuk menarik perhatian khalayak yang dilakukan oleh Grab.

Mungkin, untuk menarik perhatian khalayak dengan memberikan banyak kode promo yang dilakukan oleh Grab atau mungkin dari OVO itu kalau di awal-awal itu tahun 2018 itu malah kita ada promo untuk menarik khalayak banyak itu menggunakan promo menarik banget. Setiap pemesanan yang menggunakan transportasi baik itu grab atau OVO itu bayarannya cukup Rp1. Terus kedua mungkin dengan kita menggunakan event-event tertentu namanya yang ditunjukkan ke khalayak luas sih gitu, kaya contohnya tahun lalu itu pernah dengar kalau Festival Lalala yang di Orchid Lembang. Itu yang konsernya itu adanya di Orchid Lembang kita ngundang apa namanya penyanyi penyanyi internasional dan penyanyi dalam negeri juga sih, dan juga dari itu kita mengadakan konser di Lembang itu sponsornya langsung kita. Saat ini siapa sih yang gatau Lembang kan ya, lembang udah jadi tempat favorit wisatawan juga, jadi itu bisa membuat event berjalan lancar. Nah di sana juga udah ada spot khusus untuk driver yang untuk para pengunjung agar bisa diorder pas mau pulang gitu. Kalau misalkan nih Dhea datang ke event itu nggak usah pesan Grab dulu terus nunggu driver datang itu gak usah. Jadi emang ada driver disana yang standby sih untuk event itu gitu. itu sih beberapa cara menarik perhatian khalayak. Intinya yang paling mudah buat buat apa namanya, buat menarik ya, menarik mata pandangan khalayak sih dengan ini, dengan promo pastinya. Kita sih dalam menentukan pangsa pasar ya untuk ngadain event kaya konser gini sih yang paling utama yang harus kita perhatikan itu target audience konser kita nih siapa, terus tempatnya mereka suka ga, terus guest star nya siapa gitu. Jadi kalo kita pikirin yang bener pasti acaranya sukses. (Rabu, 29 Juli 2020 pukul 08.30 WIB)

Cara yang dilakukan dalam strategi menarik perhatian khalayak yang dilakukan Grab yaitu diantaranya adalah mengeluarkan promosi yang sangat menarik perhatian publik dengan menawarkan promo yang benar-benar membuat orang tertarik untuk menggunakan Grab sebagai jasa antar online 
bagi konsumen yaitu dengan hanya membayar Rp.1 saja seseorang bisa menggunakan jasa ojek atau taksi online dengan membayar menggunakan OVO. Selain dengan adanya promo ini, dalam upaya menarik perhatian khalayak, Grab juga mengadakan sebuah festival atau konser yang pada tahun 2019 dengan bertemakan event yang mengundang berbagai penyanyi dan band lokal dan internasional yang tentunya event itu berjalan dengan sukses dan diminati berbagai kalangan.

Berbagai macam promo dan yang disediakan Grab untuk penggunanya cukup bisa menarik perhatian, seperti yang dikatakan oleh Bapak Aliul selaku driver Grab yang sudah bekerja selama 3 tahun menjadi supir taksi online Grab.

Ya neng, kalo lagi ada promo tuh ya neng, orang-orang yang make Grab sih biasanya ga ketinggalan pake promo Grab ya daripada angkot misalnya, mungkin karena mereka ngerasanya lebih praktis aja ya, ganunggu lama juga mereka kalo pesen Grab ya, bayarnya lebih murah lagi, itu kan yang dikejar orang-orang, murahnya itu haha. (Kamis, 23 Juli 2020 Pukul $10.00 \mathrm{WIB})$

Berbagai bentuk promosi membuat Grab lebih sering digunakan dan dinilai berhasil dalam menarik perhatian pengguna untuk menggunakan Grab yang bisa mereka andalkan. Metode pembayaran OVO juga sangat berpengaruh besar dalam Grab dan lebih banyak mendapatkan promosi apabila menggunakan OVO, seperti yang dikatakan oleh Bapak Aril berikut.

Jelas, jelas banget, apa namanya kalau misalkan, Dhea pakai Grab transportasi ataupun bayar tapi menggunakan OVO itu nanti Dhea pertama akan mendapatkan Cashback dalam OVO poin, yang kedua itu kalo Dhea pesen entah Grab Food atau Transportasi, selain mendapatkan apa namanya Cashback OVO ya itu Dhea nanti akan mendapatkan poin reward nah kalau kumpul-kumpul kekumpul banyak nih reward nya banyak Nanti Dhea bisa melakukan pertukaran poin sama outlet yang udah kerja sama dengan kita. Liatnya gimana sih di aplikasinya? tinggal liat aja di aplikasi Grab itu yang paling kiri di pojok pojok kanan bawah, yang akun, nah yang poin. nah itu kalo udah kekumpul bisa kita tukarkan ke outlet yang udh kerjasama sama kita. misalnya Dhea mau ke salon nih pakai diskon dan potongan dari poin yang udah dikumpulin, contoh punya poin 1000 rata-rata ada penukaran poin dengan 1000 poin. Apakah terpotongan Rp.50.000 atau berapa gitu Nah ini bisa digunakan di salon yang ada di daerah kamu gitu. (Rabu, 29 Juli 2020 pukul 08.30 WIB)

Penggunaan OVO, selain mendapatkan promosi lebih, dalam Grab juga ketika menggunakan OVO bisa menghasilkan cashback yang tentunya 
membuat keuntungan bisa berkali-kali lipat yang mana cashback ini bisa digunakan sebagai koin untuk nantinya bisa dipakai kembali ketika pengguna Grab menggunakan layanan Grab kembali. Metode pembayaran OVO juga dinilai lebih efektif daripada membayar secara tunai atau cash oleh para pengemudi dan konsumen sebagai pengguna Grab.

Menurut hasil penelitian dari beberapa informan, strategi Marketing Public Relations dalam taktiknya untuk menarik perhatian konsumen (Pull Strategy) yaitu dengan menggunakan voucher promosi, mengadakan event-event dan memberikan koin sebagai reward setelah pemakaian Grab.

Berdasarkan pernyataan yang diberikan Bapak Aril selaku Business Development Grab Bandung, ketika Grab sudah dikenal luas oleh mayarakat, Grab juga mempertahankan publik agar bisa tetap menjadi pelanggannnya dengan mengadakan event yang terkenal pada saat itu di tahun 2019 dengan Festival Lalala yang mengundang penyanyi dan artis internasional. Pada saat itu, konser sangat diminati kaum muda sebagai salah satu hobi mereka, yaitu menonton konser.

Ruslan (2012:246) menyebutkan bahwa strategi Marketing Public Relations dalam menarik perhatian atau Pull Strategy berfungsi untuk melakukan komunikasi yang dilakukan oleh pemberi informasi mengenai produk atau jasa yang dihasilkan perusahaan yang dapat dipercaya dan dalam kegiatan menarik perhatian publik diharapkan bisa menciptakan kesan positif terhadap perusahaan.

Event yang diselenggarakan Grab bisa mencapai tujuan perusahaan dengan bisa memberikan kesan positif terhadap perusahaan setelah target atau audience menghadiri event tersebut. Grab juga memberikan informasi mengenai perusahaan Grab kepada audinece dalam acara tersebut.

Selain iklan dan event, salah satu hal yang bisa merakir perhatian publik untuk menngunakan jasa Grab yaitu dengan adanya promosi. Pada awal Grab diluncurkan di Indonesia, Grab pernah memberikan promo atau discount berupa hanya membayar Rp.1 pengguna Grab bisa memakai jasa layanan Grab dengan membayar melalui OVO. Discount itu berhasil menarik perhatian pelanggan. Promosi yang telah dilakukan Grab untuk menarik perhatian pengguna juga yaitu dengan memberkan reward atau voucher bagi pengguna yang telah menggunakan aplikasi Grab sebelumnya. Reward dan voucher akan dihasilkan jika menggunakan OVO sebagai alat pembayaran pengguna. Baik OVO maupun Grab bisa memberikan keuntungan kepada pengguna dengan memberikan discount, voucher dan reward guna menjadi Pull Strategy Grab.

\section{Strategi Marketing Public Relations dalam Mendorong Minat}




\section{Pengguna Grab}

Push Strategy Grab dengan upaya untuk mendorong minat pengguna dalam pemakaian Grab menggunakan media sosial salah satu medianya. Media sosial yang digunakan dalam strateginya yang paling sering digunakan yaitu instagram dan twitter. Kedua media sosial ini dipilih karena keduanyalah yang paling banyak diminati dan digunakan oleh masyarakat Indonesia.

Melihat dari peminat rata-rata pengguna Grab yang berusia muda yang menggunakan smarthhone sebagai kebutuhan primernya, Grab menggunakan media sosial sebagai alat menyebarkan iklan untuk mendorong minat pengguna dalam menggunakan Grab secara berkala. Berikut adalah hasil wawancara bersama Bapak Aril.

Sama kayak tadi pertanyaan sebelumnya sih, Ya kurang lebih sama. Kalau namanya Strategi apa namanya sama. Kalau bentuk iklannya itu jelas ya ada itu namanya di Instagram yang akan kita ada instastory, Instagram sih ini paling bagus ya apa namanya, iklannya gitu, terus ada juga dalam bentuk video animasi, juga ada misalkan video langsung apa namanya kayak video terbaru komedi juga gitu jadi dilakukan di instastory di Instagram itu, di feed juga ada sih, ada video yang kita buat langsung entah itu video animasi atau video langsung sih. Terus di Ig juga kita bisa ngobrol ngorol juga sama followers sih untuk kiat kiat kita menjaga reputasi juga ya. (Rabu, 29 Juli 2020 pukul 08.30 WIB)

Hasil wawancara menyebutkan bahwa media sosial berupa instagram sangat membantu dalam taktik mendorong minat khalayak. Iklan-iklan yang muncul di instastory maupun informasi mengenai Grab yang dibagikan di instagram membuat Grab semakin banyak peminatnya.

Pada saat ini, hampir semua orang di Indonesia sudah mengenal dan mengetahui apa itu Grab dan dengan adanya media Instagram sebagai salah satu media yang membantu banyak dalam pengiklanannya, taktik ini juga membuat Grab bisa lebih bisa berinteraksi dengan pengguna dan khalayak umum lainnya sebagai cara Grab untuk menjaga hubungan baik dengan konsumen.

Menurut Bapak Aril sebagai salah satu informan mengatakan bahwa pemberian iklan yang dilampirkan melalui media sosial dinilai efektif dan memberikan lebih banyak respon positif. Media sosial selain menjadi media promosi, juga dipakai untuk memberikan informasi-informasi mengenai perusahaan.

Instagram yang dimiliki Grab juga banyak memiliki followers yang membuatnya menjadi media yang bisa lebih dapat dipercaya oleh pengguna media sosial khususnya instagram. Secara berkala, akun instagram Grab 
mengunggah video atau foto guna membuat pengikut instagram Grab bisa merasa lebih dekat dengan Grab. Penggunggahan berupa video biasanya lebih diminati dengan diberikannya video animasi yang lebih menarik untuk dilihat.

Video dan foto yang diunggah secara berkala juga merupakan taktik dari perusahaan untuk bisa lebih dekat dengan publik eksternal dan juga bisa berkomunikasi secara timbal balik. Pengikut instaram Grab bisa berkomunikasi melalui kolom komentar yang disediakan di tiap unggahan foto maupun video.

Pada saat ini, influencer banyak sekali menarik perhatian masyarakat. Influencer adalahseseorang yang bisa memberikan pengaruh kepada masyarakat dengan kegiatan yang mereka lakukan. Media sosial menjadi media bagi mereka untuk melakukan apapun yang mereka lakukan, salah satunya dengan mempromosikan atau mengiklankan suatu produk atau jasa yang dikirimkan kepada dirinya untuk digunakan dan dipromosikan agar peminat atau pengikut mereka bisa menggunakan barang atau jasa yang sama seperti yang mereka gunakan juga.

Media sosial yang biasa mereka pakai yaitu seperti Youtube, instragram, facebook, twitter dan sebagainya. Media itu juga merupakan media yang paling banyak digunakan mayoritas masyarakat untuk mengetahui berita terbaru mengenai apapun yang mereka ingin tahu. Ketika seorang influencer melakukan suatu kegiatan baik itu sebagai kegiatan promosi ataupun kegiatan sehari-hari, pengikutnya bisa melakukan hal yang sama yang dilakukan influencer.

Menurut Bapak Aril selaku Business Development Grab yang didapat dari hasil wawancara memaparkan bahwa Grab Bandung memilih influencer untuk mempromisikan Grab sebagai strategi untuk mendorong minat khalayak agar menggunakan Grab. Influencer yang dipilih yaitu influencer yang memiliki cukup banyak pengikut atau penggemar.

Banyak influencer sebagai public figure yang mempromosikan Grab guna melakukan strategi mendorong minat khalayak untuk menggunakan Grab. grab memilih cukup banyak influencer dari setiap kota untuk mempromosikan Grab dengan menggunakan beberapa hashtag. Kegiatan ini dinilai ampuh untuk mendorong minat dengan tujuan mencapai Push Strategy Grab.

Sama halnya dalam media sosial, media yang digunakan Grab dalam mendorong minta pengguna yaitu melalui iklan yang dipasang di Youtube. Menurut hasil wawancara yang dipaparkan oleh Bapak Aril, penggunaan Youtube pada saat ini sudah sangat tidak terbendung lagi. Hampir semua 
orang menggunakan Youtube sebagai tontonan yang mereka gunakan alih-alih menggunakan televisi.

Media lainnya dalam media iklan Grab yaitu Youtube. Saat ini Youtube lebih diminati daripada Televisi. Peningkatan penggunaan Youtube membuat Youtube semakin digandrungi oleh lapak bisnis seperti Grab untuk memasang iklan sebagai Google Adsense Youtube mereka, seperti dalam wawancara yang dilakukan bersama Ibu Ribka.

Kalo berpengaruh besar di iklan itu jelas ya, Ini sebenarnya bukan Bandung sih yang bertanggung jawab untuk iklan ini tapi ke pusat ya, kalau untuk ini jelas berpengaruh banget sih, apa namanya kalau misalkan Google Adsense sendiri jelas sangat berpengaruh dan saya nggak bisa lebih jelas lagi menerangkannya karena emang ini bukan cangkupan saya gitu. intinya ini iklannya berpengaruh besar sih. Mengingat pada saat ini juga orang orang kebanyakan nontonnya buka televisi lagi kan ya, pada gila Youtube sekarang, ya pasti dengan kita memasang iklan disini akan tergambarlah untuk orang yang menonton dan tertarik juga dengan iklannya. Pokonya Youtube ini salah satu inceran iklan sih sekarang ini. (Rabu, 29 Juli pukul 10.30 WIB)

Pada hasil wawancara didapatkan informasi bahwa Youtube adalah salah satu media sebagai media pemasang iklan paling memiliki pengaruh peningkatan iklan karena banyak sekali penikmat Youtube yang bisa melihat iklan yang dipasang disana.

Google adsense youtube merupakan sebuah wadah bagi para pembisnis untuk memasangkan iklannya di laman Youtube yang bisa dilihat setiap seorang pengguna yang bisa dilihat setiap seorang pengguna Youtube menonton video Youtube.

Youtube sekarang sudah menjadi posisi pertama sebagai media yang paling banyak digunakan di Indonesia melebihi WhatsApp maupun Facebook. Pennguna Youtube juga memiliki penggemar dari berbagai kalangan usia dengan menyediakan berbagai macam konten yang bisa disesuaikan sesuai umur penonton yang membuat Youtube banyak diminati.

\section{Strategi Marketing Public Relations dalam Menggiring Opini Publik Pengguna Grab}

Pass Strategy merupakan strategi ketiga dalam Three Ways Strategy dimana strategi ini adalah strategi untuk mempengaruhi atau menggiring opini publik yang berkembang di publik eksternal. Pass Strategy berperan untuk mempertahankan strategi sebelumnya agar tujuan yang ingin perusahaan capai bisa lebih stabil dalam pencapaiannya dan dapat membuat pengguna Grab dapat memberikan nilai positif kepada perusahaan.

Peruahaan besar seperti Grab tentu tidak jauh dari opini publik yang 
berkembang di kalangan masyarakat atau publik eksternal. Publik seringkali menyimpulkan berbagai macam kasus atau kejadian dengan keinginan dan pengetahuan mereka sendiri tanpa tahu informasi mana saja yang benar. Grab memiliki cara jika ada opini yang buruk berkembang seperti hasil wawancara bersama Bapak Aril berikut.

Klarifikasi sih, kalau misalkan ada yang menyebar, kalau gitu pasti langsung klarifikasi. Tapi kalau misalkan sampai opini publik yang bener bener buruk gitu ya pasti ke pusat langsung. Kalau misalkan kayak ada apa namanya opini-opini yang kurang baik di area Bandung ya kita sendiri yang akan mengadakan klarifikasi atau yang lain yang membuat masalahnya jadi clear dan terjelaskan dengan penjelasan kami, begitu sih. Nah kalo menggiring opini sih paling kita. (Rabu, 29 Juli 2020 pukul 08.30 WIB)

Opini buruk yang berkembang di masyarakat diatasi dengan memberikan klarifikasi langsung dari perusahaan agar masyarakat dapat mengetahui kejelasan dari kasus yang berkembang, dengan klarifikasi, kejadian yang mulanya berkembang dengan berita buruk bisa berubah dengan informasi yang baik dan lebih tepat dan tidak sesuai dengan opini yang menyebar dengan informasi yang tidak benar. Opini publik yang berkembang di masyarakat menurut Bapak Aril dari hasil wawancara penelitian sebagai berikut.

Apa ya, paling gini sih misalkan yang saya tahu, misalkan di daerah Garut Jawa Barat, orang-orang di sana itu kalau misalkan order mobil via online disebutnya Grab. kalau misalkan pesan order motor, ojol Grab itu mereka akan menyebut sebutannya itu ojek sebelah, hahaha. Saya juga kurang paham sih kenapa ya, ya itu yang berkembang di masyarakat dan it's okay sih. Jadi kalo mau dirangkum sih Grab itu udah terkenal, bukan terkenal sih, tapi lebih dikenal oleh orang orang itu transportasi mobilnya gitu. Kalo kompetitor sebelah terkenalnya makanannya, Food Food itu. (Rabu, 29 Juli 2020 pukul 08.30 WIB)

Berdasarkan hasil wawancara yang dilakukan bersama Bapak Aril, opini yang berkembang mengenai Grab dalam waktu dekat ini cukup baik dan tidak ada isu buruk yang berkembang mengenai Grab. Seiring waktu, ketenaran Grab juga sudah tidak dihindari lagi khususnya di kota-kota besar di Indonesia. Opini publik yang berkembang tidak selalu opini baik saja, ada juga opini buruk yang pernah dirasakan oleh Grab dan cara menggiring opini buruk yang berkembang di masyarakat dijelaskan oleh Bapak Aril sebagai berikut.

Selama ini sih selama saya kerja di Grab itu gaada ya opini buruk itu 
yang berkembang diluaran tentang Grab. Paling dulu sih itu yang ada mitra Grab yang beritanya itu mencabuli penumpang iu. Mitra di Grab itu driver ya, kami sebut mitra. Itu ada di tahun 2017 sebelum saya kerja di Grab. Dan penumpangnya itu pesan ojolnya bukan lewat aplikasi, jadi korban sama pelakunya udah kenal gitu katanya, terus adalah kejadian itu. Pihak Grab langsung sih klarifikasi, Grab pusat ya itu tugasnya, nah Grab juga langsung memutuskan kemitraan sama drivernya ini gitu. Grab juga bertanggung jawab sama korbannya dan bekerjasama juga sama kepolisian. Sayangnya Grab gabisa ngasih liat jejak digital penumpang sama driver sih karena korban pesen drivernya gapake aplikasi, jadi ga ketahuan sama Grabnya, dan berita itu udh clear sih dan menggiring opininya juga bisa diatasi karena kan itu bukan kesalahan Grab ya, dan korban juga salahnya ga mesen langsung di aplikasinya gitu, pelaku juga udah kena ganjarannya juga. (Rabu, 29 Juli 2020 pukul 08.30 WIB)

Berdasarkan pernyataan informan, opini publik buruk yang berkembang dapat dituntaskan dengan klarifikasi yang baik dari pihak perusahaan. Jika ada kendala atau masalah lain maka perusahaan akan mejelaskan dan bertanggungjawab penuh atas apa yang terjadi jika opini buruk yang berkembang itu murni kesalahan dari perusahaan. Adanya kejadian yang menyebabkan buruknya opini ini merupakan bukan sepenuhnya kesalahan Grab, meskipun demikian, perusahaan Grab telah mengkondisikan orang yang telah dirugikan dan bertanggungjawab serta bertindak tegas pada mitra (driver) yang melakukan kesalahan.

Ruslan (2012:247) menyebutkan bahwa Pass Strategy yang dilakukan oleh Marketing Public Relations yaitu mengupayakan segala bentuk penggiringan atau pembentukkan opini publik yang akan dan sedang berkembang di masyarakat dengan tujuan meningkatkan citra baik perusahaan dan menjaga reputasinya.

Menurut Jafkins (2003:86) pameran atau event seperti yang diselenggarakan Grab adalah salah satu media komunikasi yang bisa membuat publik mengenal produk/jasa dan mampu mengingatnya. Event Festival Lalala (dalam lampiran Festival Lalala) juga diharapkan bisa menjadi media komunikasi yang Grab berikan kepada publik untuk bisa menjadikan Grab sebagai perusahaan penyedia jasa layanan perjalanan online yang bisa digunakan oleh khalayak luas.

Grab merupakan perusahaan besar yang tidak luput dari pembahasan public mengenai apa saja yang ada didalamnya. Perusahaan besar seperti Grab tentu pernah mendapatkan opini publik yang buruk di masyarakat. Menurut Bapak Aril selaku informan mengatakan bahwa opini publik yang 
berkembang mengenai Grab selama ini belum pernah ada berita yang benarbenar bisa merugikan perusahaan jika atas dasar kesalahan perusahaan.

Penyebaran informasi baik itu informasi yang sesuai dengan fakta atau hanya hoaks belaka pada zaman teknologi ini sangat cepat berkembang dimana media sosial menjadi alat penyebaran berita yang sangat cepat dan tak terkendali.

Menurut Bapak Aril selaku informan, tindakan yang dilakukan Grab jika ada opini publik yang buruk yang bisa merugikan perusahaan menurut Bapak Aril adalah melakukan klarifikasi yang mengundang banyak media untu memberikan dan membersihkan informasi yang sudah tersebar dan menjelaskan kebenarannya. Hal tersebut sudah terbukti bisa membuat opini publik buruk yang berkembang bisa hilang dan kembali memperbaiki citra buruknya.

\section{PENUTUP}

Berdasarkan hasil penelitian dan pembahasan yang didapatkan, maka kesimpulannya adalah sebagai berikut.

Pertama. strategi Marketing Public Relations Grab untuk merarik perhatian khalayak menggunakan pembayaran OVO yaitu dengan mengadakan event-event dengan mengambil tema yang banyak diminati oleh pengguna Grab. Selain event, Grab juga memberikan berbagai macam promo menarik serta discount yang menghasilkan reward dan point setelah menggunakan OVO. Grab juga membuat iklan -iklan untuk menarik perhatian khalayak.

Kedua, strategi Marketing Public Relations Grab untuk mendorong minat pengguna menggunakan pembayaran OVO yaitu dengan menggunakan media sosial sebagai media atau alat untuk melakukan periklanan, media sosial yang sering digunakan dalam pemasangan iklan yaitu instagram dan twitter sebagai media sosial yang paling banyak digunakan kaum muda sebagai pengguna Grab. Selain media sosial, untuk mendorong minat pengguna Marketing Public Relations Grab menggandeng beberapa public figure sebagai influencer untuk mengajak orang orang menggunakan Grab. Periklanan Grab guna mendorong minat pengguna juga dipasang di Youtube.

Ketiga, strategi Marketing Public Relations Grab untuk menggiring opini publik yaitu dengan memberikan informasi yang benar terkait jasa yang Grab tawarkan di berbagai media sosial sebagai alat penyebar informasi tercepar saat ini. Jika ada masalah atau berita buruk sebagai opini publik tidak baik yang tersebar maka perusahaan akan mengadakan klarifikasi 
dengan mengundang berbagai media untuk melakukan liputan agar masyarakat luas tidak termakan berita yang tidak benar.

\section{DAFTAR PUSTAKA}

Abadi, Saka. 1994. Marketing Public Relations Upaya Memenangkan Persaingan.

Jakarta: Lembaga Management Feui.

Abdillah. 2017.Efektivitas Marketing PR Dalam Membangun Citra Perusahaan

Telekomunikasi. Jurnal Ecodemica.Vol.01 No.01.

Abdurrachman, Oemi. 2001. Dasar-Dasar Public Relations. Bandung: Citra Adhitya Bakti.

Ardianto, Elvinaro. 2014. Handbook Of Public Relations. Bandung :Simbiosa

Rekatama Media.

Padjajaran

. 2011. Public Relations Praktis. Bandung: Widya

Public Relations.

Cetakan Ketiga. Bandung: Remaja Rosdakarya.

Agung, Silih, Wasessa dan Jim Macnamara. 2010. Strategi Public Relations. Jakarta: PT Gramedia Pustaka Utama.

Bungin, Burhan. 2011. Metode Penelitian Kualitaits Metodologis Ke Arah Ragam

Varian Kontemporer. Jakarta: PT Raja Grafindo Persada. . 2009. PenelitianKualitatif, Jakarta : Kencana

Cutlip, Center, Groom. 2005. Effective Public Relations.Jakarta: Kencana.

Effendy, Onong Uchjana. 1989. Ilmu Komunikasi Teori dan Praktek. Bandung,

PT. Remaja Rosda Karya

Fahri. 2018. Strategi Marketing Public Relations Go-Food dalam Pembentukan

Citra Perusahaan di Kota Surabaya. Jurnal Ilmu Komunikasi. Vol.2, No 2.

Hariyanto, D. 2018. Memenangkan Persaingan Bisnis Produk Farmasi Melalui

Marketing Public Relations. Jurnal Manajemen Pemasaran. Vol.02, No.02

Hukmah. 2018.Analisis Faktor yang Menjadi Kepusan Penumpang Grab.Journal

of Communications Scences. Vol.01, No.01

Iriantara, Yosal. 2004. Community Relations: Konsep dan Aplikasinya. 
Bandung:

Simbiosa Rekatama Media.

Irianti, Lydia Jaya. 2018. Marketing Public Relations dalam Meningkatkan Loyalitas

Pelanggan. Jurnal Ilmu Hubungan Masyarakat Vol.3, No.3

Jefkins, Frank. 1992. Public Relations (Edisi Keempat). Jakarta: Erlangga

Kasali. 2003. Manajemen Public Relations. Jakarta: Pustaka Utama Grafiti.

Kotler dan Keller. 2008. Manajemen Pemasaran, Edisi 12. Jakarta: Erlangga.

Kriyanto, Rahmat. 2006. Teknik Praktis Riset Komunikasi. Jakarta: Kencana

Prenada Media Group

Kusrianto, Adi. 2007. Pengantar Desain Komunikasi Visual. Yogyakarta: Penerbit Andi.

Mulyana, Deddy. 2003. Metodologi Penelitian Kualitatif. Bandung: PT Remaja Rosda Karya.

Limakrisna, N. 2017. Pengaruh Komunikasi Pemasaran dan Kerelasian nasabah

terhadap Loyalitas Nasabah. Jurnal Ilmiah Ekonomi Bisnis.Vol.2, No.02.

Ridho, Muhammad. 2019. Analisis Tingkat Kepuasan Dan Performa Pada

Merchant OVO Di Surabaya. Jurnal Sains Dan Seni ITS. Vol.8, No.1.

Rosyidi, Imron. 2009. Pentingnya Human Relations Dalam Kegiatan Public

Relations. Ilmu Dakwah: Academic Journal For Homiletic Studies. Vol.04

No.13

Ruslan, Rosady. 2008. Manajemen Public Relations \& Media Komunikasi Konsepsi

Dan Aplikasi. Jakarta: RajaGrafindoPersada. . 2012.MetodePenelitian Public Relations dan Komunikasi.

Jakarta :Raja Grafindo Persada.

Saifuddin, Azwar. 1997. Metode Penelitian. Jogyakarta: Pustaka Pelajar.

Soemanagara, Dermawan. 2006. Marketing Communications, Taktik dan Strategi.

Jakarta: PT Buana Ilmu Populer. 
D. Salsabila Royan, A.S Haris, L. Imelda 